\title{
ANALISIS BENTUK DAN FUNGSI REFERENSI PERSONAL DALAM NOVEL REMBULAN TENGGELAM DIWAJAHMU KARYA TERE LIYE
}

\author{
Muh. Ali Imran' ${ }^{1}$ Nur Resky Evawanti² \\ Fakultas Keguruan dan Ilmu Pendidikan, Universitas Muhammadiyah Makassar \\ ali.imran@gmail.co.id \\ Fakultas Keguruan dan Ilmu Pendidikan, Universitas Muhammadiyah Makassar \\ risky.nur@gmail.com
}

\begin{abstract}
The main problem in this research how to find out about the form and function of personal references in the novel Rembulan Tenggelam di Wajahmu in order to determine the differences contained in the novel especially those on personal references contained therein. This research was a literature review of research that contains one topic that contains some ideas or propositions related and must be supported by the data obtained from literature sources. This research procedure included planning, action and analysis. Subjects in this study was the novel of Rembulan Tenggelam di Wajahmu. The results showed that the observation of novel moon sinking in the face are analyzed on personal references indicate that there are a lot of words including personal references such as personal pronoun first (referring to himself), pronouns second person (referring to the speaker), and the third person pronoun (which refers to the person in question). Based on these results above, it can be concluded that the words include references persona there are differences both in writing and in speech.
\end{abstract}

Keywords: Novel, personal references

\begin{abstract}
Abstrak
Masalah utama dalam penelitian ini yaitu bagaimana mengetahui tentang bentuk dan fungsi referensi personal di dalam novel Rembulan Tenggelam di Wajahmu dengan tujuan untuk mengetahui perbedaan yang terdapat di dalam novel tersebut terkhusus pada referensi personal yang terdapat di dalamnya. Jenis penelitian ini adalah penelitian kajian pustaka yang berisi satu topik yang memuat beberapa gagasan atau proposisi yang berkaitan dan harus didukung oleh data yang diperoleh dari sumber pustaka. Prosedur penelitian ini meleputi perencanaan, pelaksanaan tindakan, dan analisis. Subjek dalam penelitian ini adalah novel rembulan tenggelam di wajahmu. Hasil penelitian menunjukkan bahwa pada pengamatan terhadap novel rembulan tenggelam di wajahmu yang menganalisis tentang referensi personal menunjukkan bahwa terdapat banyak kata-kata yang termasuk referensi personal seperti pronomina persona pertama( yang mengacu pada diri sendiri), pronomina persona kedua (yang mengacu pada lawan bicara), dan pronomina persona ketiga (yang mengacu pada orang yang dibicarakan). Berdasarkan hasil penelitian tersebut diatas, dapat disimpulkan bahwa kata-kata yang mencakup referensi persona terdapat perbedaan baik didalam penulisan maupun didalam tuturan.
\end{abstract}

Kata kunci: Novel,referensi personal

\section{PENDAHULUAN}

Ketika membicarakan pandangan semantik hubungan antara kata dengan bendanya adalah hubungan referensi: katakata menunjuk benda. Pandangan kaum tradisional ini terus berpengaruh dalam bidang linguistik (seperti Semantik Leksikal) yang menerangkan hubungan yang ada itu adalah hubungan antara bahasa dengan dunia (benda) tanpa memperhatikan si pemakai bahasa tersebut. Tetapi Lyon pada pernyataan yang terbaru, ketika 
membicarakan referensi tanpa memperhatikan si pembicara tidaklah benar. Si pembicara yang paling tahu tentang referensi kalimatnya.

Dari keterangan tersebut, dapat kita ketahui bahwa pada analisis wacana referensi itu dianggap sebagai tindak tanduk dari si pembicara atau si penulis. Dengan kata lain, referensi dari sebuah kalimat sebenarnya ditentukan oleh si pembicara atau si penulis. Kita sebagai pembaca atau pendengar hanya dapat menerka apa yang dimaksud (direferensikan) oleh si pembaca atau si penulis.

\section{METODE PENELITIAN Rancangan Penelitian}

Pendekatan yang digunakan di dalam penelitian ini ada dua, yaitu secara teoretis dan secara metodologis. Secara teoretis yang digunakan adalah pendekatan analisis wacana, yaitu pendekatan yang mengkaji wacana baik secara internal maupun eksternal dengan tujuan untuk mengungkapkan kaidah bahasa yang mengkonstruksi wacana, pemproduksian wacana, pemahaman wacana, dan pelambangan suatu hal dalam wacana dalam fungsinya sebagai alat komunikasi.

\section{Data dan Sumber Data}

Sumber data dalam penelitian ini adalah wacana tulis yang mengandung referensi. Pemilihan wacana tulis dalam sumber data dalam penelitian dengan mempertimbangkan beberapa aspek. Wacana tulis memiliki referensi yang menjadi aspek penelitian ini.Wacana merupakan sebuah struktur kebahasaan yang luas melebihi batasan-batasan kalimat, sehingga dalam penyusananya hendaknya selau mengguanakan bentuk tulis yang efektif.

\section{Teknik Pengumpulan Data}

Teknik pengumpulan data dalam penelitian ini adalah metode simak.

\section{Teknik Analisis Data}

Metode yang digunakan dalam penelitian ini adalah metode agih, yaitu metode yang alat penentunya merupakan bagian dari bahasa yang bersangkutan, yaitu berupa wacana tulis yang dibentuk dengan menggunakan bahasa. Teknik dasar yang digunakan adalah teknik bagi unsur langsung yaitu cara yang digunakan pada awal kerja analisis dengan membagi satuan lingual data menjadi beberapa bagian atau unsur, dan unsur-unsur yang bersangkutan dipandang sebagai bagian yang langsung membentuk satuan lingual yang dimaksud (Sudaryanto 1993:31). Jadi wacana yang dianalisis berupa penggalan-penggalan wacana yang terdiri atas klausa dan kalimat.

\section{HASIL PENELITIAN DAN PEMBAHASAN}

Referensi merupakan penggunaan kata atau frasa untuk menunjuk atau mengacu kata, frasa, atau mungkin juga satuan gramtikal yang lain. Dengan demikian, dalam penunjuk terdapat dua unsur yaitu unsur penunjuk dan unsur tertunjuk. Referensi persona merupakan salah satu cara yang digunakan untuk membuat keutuhan topik dalam sebuah paragraph, yaitu dengan menggantikan antaseden dengan menggunakan pronomina persona.

Pronomina merupakan kelas kata yang berfungsi sebagai pengganti nomina.Pronomina persona digunakan dalam sebuah wacana yang mengacu kepada orang atau bisa disebut kata ganti orang.

Dalam penelitian ini ditemukan tiga jenis referensi persona yaitu referensi persona pertama (mengacu pada diri sendiri), 
referensi persona kedua (mengacu pada

lawan bicara), referensi persona ketiga

(mengacu pada orang yang dibicarakan).

Tabel 1. Referensi persona pertama (mengacu pada diri sendiri)

\begin{tabular}{|c|c|}
\hline Teks bacaan & Makna \\
\hline $\begin{array}{l}\text { Malam ini kita akan membicarakan panti } \\
\text { asuhan tempat anak-anak kurang beruntung } \\
\text { ditampung. (RTDW, 2009:3) }\end{array}$ & $\begin{array}{l}\text { Makna kata kita pada penggalan } \\
\text { teks disamping menunjukkan } \\
\text { penulis dan pembaca bahwa penulis } \\
\text { mengajak kepada pembaca tentang } \\
\text { hal-hal yang akan diceritakan pada } \\
\text { buku ini. Penulis akan menceritakan } \\
\text { tentang kejadian-kejadian dipanti } \\
\text { asuhan tempat awal cerita ini } \\
\text { dimulai. }\end{array}$ \\
\hline $\begin{array}{l}\text { Padahal kau tahu Ray, aku memiliki } \\
\text { kesempatan untuk melihat wajah keadilan } \\
\text { yang tidak kasat mata. Ah, sayang } \text { kita selalu } \\
\text { menurutkan perasaan dalam urusan ini. Kita } \\
\text { selalu berprasangka buruk. Kita membiarkan } \\
\text { hati yang mengambil alih, menduga-duga. } \\
\text { Tidak puas menduga-duga, kita membiarkan } \\
\text { hati mulai menyalahkan, mengutuk } \\
\text { semuanya. Kemudian tega sekali, menjadikan } \\
\text { kesalahan orang lain sebagai pembenaran } \\
\text { atas tingkah laku keliru kita. (RTDW, } \\
\text { 2009:200) }\end{array}$ & $\begin{array}{l}\text { Pada penggalan teks disamping kata } \\
\text { kita bersifat ekskulisif artinya tidak } \\
\text { terpacu hanya menujukkan } \\
\text { pembicara dan lawan bicara dalam } \\
\text { hal ini adalah Ray dan malaikat } \\
\text { tetapi untuk sipembaca. Kebiasaan } \\
\text { yang sering terjadi di lingkungan } \\
\text { masyarakat tentang keadilan yang } \\
\text { kita lihat dari sudut pandang kita } \\
\text { saja dan lebih sering melibatkan hati } \\
\text { dan perasaan sehingga keadilan } \\
\text { yang bisa dilihat kasat mata buram } \\
\text { hampir tak terlihat. }\end{array}$ \\
\hline $\begin{array}{l}\text { Kalau kita gagal malam ini, setidaknya ia } \\
\text { menjadi atlet lari yang baik, ditambah enam } \\
\text { bulan latihan lagi mungkin dia bisa } \\
\text { memenangkan lomba lari } \\
\text { 2009:179) }\end{array}$ & $\begin{array}{l}\text { Makna kata kita pada penggalan } \\
\text { teks disamping menujukkan Plee } \\
\text { dan Ray, tetapi dalam kondisi Plee } \\
\text { yang berbicara kepada dirinya } \\
\text { sendiri atau kepada sipembaca yang } \\
\text { merencanakan sebuah rencana jika } \\
\text { rencana yang akan dilakukannya } \\
\text { sekarang gagal setidaknya Ray yang } \\
\text { menjadi tokoh utama dan sekaligus } \\
\text { teman untuk menjalankan rencana } \\
\text { itu bisa menjadi atlet lari dari } \\
\text { kelebihannya yang sangat cepat } \\
\text { dalam hal berlari. }\end{array}$ \\
\hline
\end{tabular}


Jika kita cermati dengan baik terdapat perbedaan fungsi kata "kita" pada empat penggalan teks diatas, dimana pada paragraf pertama kata kita mengacu pada pengarang yang menyampaikan kepada pembaca tentang hal yang akan diceritakan dalam buku dan paragraf kedua kata kita bersifat ekskulisif artinya tidak hanya menujukkan orang yang berbicara dan lawan bicara yang ada di dalam cerita, tetapi pengarang ingin menujukan pembaca masuk didalam area imajinasi pengarang yang ada didalam cerita itu agar pembaca lebih mudah memahami.

Kata kita pada teks yang ketiga mengacu pada Plee dan Ray tetapi pada penggalan teks ini hanya Plee yang berbicara pada dirinya sendiri untuk dipahami oleh sipembaca tentang apa yang dipikirkannya saat itu.

\section{Teks bacaan}

\section{Makna}

Pelayan yang diteriaki mengecek kertas ditangannya dan salah tingkah. "Maaf, saya keliru." Berbasa basi hendak menarik nampan dari hadapan gadis itu. (RTDW, 2009:226)

"Sepertinya $\boldsymbol{a} \boldsymbol{k} \boldsymbol{u}$ tidak salah jadwal, bukan?" Lelaki setengah baya itu tertawa melihat Ray. (RTDW, 2009:268)
Kata saya pada penggalan teks diatas menunujukkan pelayan yang keliru dan meminta maaf merasa bersalah tehadap sosok perempuan yang diceritakan oleh penulis.

Kata $\boldsymbol{a k} \boldsymbol{u}$ pada penggalan teks disamping meunjukkan lelaki setengah baya yang merasa tidak bersalah terhadap Ray yang menjadi pemeran utama.
Jika kita memperhatikan kata ganti $\boldsymbol{a k u}$ dan saya pada kedua teks tersebut mempunyai kedudukan yang sama yaitu sebagai kata ganti nama diri sendiri, tetapi jika kita cermati lebih seksama kata tersebut memiliki makna dan fungsi yang berbeda, dimana kata $\boldsymbol{a} \boldsymbol{k} \boldsymbol{u}$ lebih menyombongkan dan terasa setara pembicara dan lawan bicara sedangkan katasaya lebih terasa santun dan lebih arif menggambarkan rasa bersalah dibanding kata aku walaupun situasi yang terdapat pada bacaan yang digambarkan oleh penulis itu sama yaitu sama-sama dalam keadaan keliru dan bersalah.

\section{Teks bacaan}

\section{Makna}

Malam ini karnaval hari raya, kesenangan melingkupi kota kami. Beduk digebuk bertalu-talu dalam irama rupa-rupa. (RTDW,2009:01)
Pada penggalan teks disamping kata kami menunujukkan bahwa penulis menjelaskan keadaan kota pada saat hari raya yang sedang berlangsung dikota tokoh utama.
Pada penggalan wacana kata kami merupakan penanda referensial persona yang berfungsi mempersonakan orang pertama jamak. Penanda referensi kami bersifat eksklusif yatu mengacu terhadap pembicara dan orang lain dipihaknya, tidak mencakupi 
prang-orang lain yang ada dipihak lawan

bicara.

Tabel 2. Referensi persona kedua (mengau pada lawan bicara)

Teks bacaan

"Apa tinggal diluar panti semenyenagkan ini?" Diar bertanya pelan, setelah sekian detik mengamati jaket kulit tersebut juga sepatu keren yang dipakai Reyhan. "Tentu saja. Kau bisa makan semaumaunya. Kau tidur semau-maunya. Tidak ada yang memaksamu bangun subuhsubuh. Bekerja jadi jongos seperti ini. Dimarahi,dipukuli” Reyhan berkata ringan. (RTDW, 2009:24)

\section{Makna}

Makna kata $k a \boldsymbol{u}$ pada penggalan teks disamping menunjukkan bahwa Reyhan memberitahukan kepada kepada Diar tentang keadaan diluar panti yang sangat menyenangka bagi Reyhan. Dia bisa makan semaunya dan tidur semaunya, tidak seperti keadaan dipanti yang memaksa mereka untuk tidur dan bangun subuhsubuh serta bekerja jadi jongos seperti yang dilakukan oleh Diar saat ini.

Makna kata kau pada penggalan teks dsamping menujukkan Rayhan yang perjalanan hidupnya begitu berliku mulai dari tertukar pada saat masih kecil yang membuat Rayhan menjadi seorang penjahat karena dia menyesali keadaan yang menimpanya dan selalu menyalahkan kedaan jika tidak sesuai dengan keinginannya. Karena yang berbicara adalah pengarang yang digambarkan sebagai malaikat yang menemani Reyhan melihat sisi kehidupannya dahulu yang belum dia ketahui. pembenaran. (RTDW, 2009:213)

Rinai ingin bertanya langsung kepada- Makna kata Engkau pada penggalan $\mathrm{Mu}$ tanpa perntara. Maka kepalanya teks disamping menunujukkan Tuhan mendongak keatas, mancari muka-Mu yang maha Esa yang menjadi tumpuan yang konon katanya ada dimana-mana. harapan Rinai yang selama ini Menggetarkan sekali menyimak memiliki begitu benyak pertanyaan percakapan tanpa suara itu. Karena, tentang kehidupannya yang tak pernah Engkau selalu menjawab setiap terjawab dan dia bertanya langsung pertanyaan. Jawaban yang sempurna, kepada Tuhan tentang pertanyaan tidak lebih tidak kurang. (RTDW, hidupnya selama ini, dan Rinai 2009:5) berharap akan dijawab oleh-Nya. 
Jika kita perhatikan kata kau pada kedua penggalan teks diatas sering tertuju pada tokoh utama dan kisahnya sering diceritakan oleh orang yang menjadi lawan bicara sang tokoh dan juga pengarang yang memperjelas keadaan tokoh pada saat diceritakan.

Pada penggalan teks pertama kata kau berfungsi menujukkan orang yang mempunyai hubungan akrab, tanpa memandang umur dan status sosial yang digambarkan oleh Ray dan Diar yang telah bersahabat sejak lama. Pada penggalan teks yang kedua kata $\boldsymbol{k a u}$ berfungsi menunjukkan orang tua terhadap orang muda yang telah dikenalnya dengan baik dan lama yang digambarkan oleh orang tua yang disebut oleh Rayhan adalah malaikat yang menemaninya menelusuri perjalanan hidupnya yang belum dia ketahui. Dan penggalan teks yang ketiga, kata Engkau berfungsi menunjukkan Tuhan yang maha esa yang menjadi tempat curahan hati dan tempat meminta segala permohonannya.

\section{Tabel 3. Referensi persona ketiga (mengacu pada orang yang dibicarakan)}

\section{Teks bacaan}

Gadis kecil itu sedang sedih. Ia tidak tahu apa itu hari raya. Ia tidak mengerti ketika teman-temannya ramai bercerita tentang makan besar besok. Ramai berceloteh soal hadiah-hadiah yang banyak terkirimkan ke Panti mereka seminggu terakhir, berebut, bertengkar. Rinai justru sedih karena tidak paham apa artinya hari raya?(RTDW, 2009:4)

Rinai rindu ayah bundanya, itulah yang Rinai paham. Tapi bagaimanalah ia akan bertemu dengan ayah bunda jika gadis kecil berkepang dua itu bahkan sejak lahir tidak pernah mengenalnya. Tiada foto walau sehelai yang menyimpan kenangan wajah. Jangankan wajah, suarapun Rinai tidak pernah mendengar. (RTDW, 2009:4)

Saat tubuh Ray hilang dikelokan, gadis itu riang menyambar setangkai bunga mawar di atas meja, hadiah Ray tadi sore. Malam itu ia tidur dengan setangkai bunga dipelukannya. (RTDW, 2009:265)

\section{Makna}

Makna kata ia pada penggalan teks disamping menujukkan Rinai yang tidak mengerti tentang hari raya, tentang makan besar, tentang hadiahhadiah yang banyak terkirim ke Panti mereka, Rai justru sedih karena tidak paham akan arti hari raya itu.

Makna kata ia pada penggalan teks disamping menujukkan Rinai yang sedang merindukan sosok ayah dan bundanya, yang dimana sejak Rinai lahir Ranai tak pernah melihat wajah bahkan mendengar suara orang tuanya.

Makna kata ia pada teks disamping menujukkan seorang gadis yang sangat senang akan setangkai bunga yang diberikan oleh Ray hingga gadis itu tidur bersama bunga yang diberikan Ray.

Usianya sekarang 37 Ray ingat sekali, Makna kata dia pada penggalan teks terakhir kali membenak sepuluh tahun disamping menujukkan Ray yang 
silam, saat melangkah bersama dengannya. Saat mengantarnya dari bangsal anak-anak rumah sakit, saat itulah dia mengatakan impian itu, "Aku bercitacita ingin membangun gedung tertinggi untukmu." Gadis itu hanya mengangguk mengiyakan. Kalau ia masih ada, gigi kelinci-nya bisa melihat mimpi itu sebentar lagi akan menjadi nyata. (RTDW, 2009:339) menceritakan impiannya kepada sang istri tentang keinginnya membuat gedung tertinggi untuknya, sedangkan kata ia pada penggalan teks disamping menujukkan pada gigi kelinci panggilan kecil istri dari Ray yang telah tiada seandainya istri Ray masih hidup dai bisa melihat mimpi itu akan sebentar lagi menjadi kenyataan.

\section{Teks bacaan}

Diar menelan ludah. Penjaga panti sok suci? Terdiam. Mereka teman sekamar di Panti. Dia tahu banyak soal itu. Ceritacerita Reyhan, kata orang-orang. Dia tahu banyak soal tabiat buruk penjaga panti. (RTDW, 2009:23)

\section{Makna}

Pada penggalan teks disamping kata dia menujukkan Diar yang tahu segala hal tentang penjaga panti yang Diar dapat dari cerita Reyhan yang menjadi teman sekamarnya selama dipanti, dan cerita orang-orang yang menceritakan tentang tabiat buruk penjaga panti.

Diar menelan ludah. Sepertinya terdengar : Pada penggalan teks disamping kata dia sibuk bertanya soal Reyhan, penjaga p dia menujukkan Diar yang tidak pernah dia tidak dipukul. Selama ini dia juga tidal dilecuti bilah rotan oleh penjaga panti Mungkin karena tubhnya yang ringkih, m mungkin karena tubuhnya yang ringkih pernah banyak ulah. Selalu rajin menyetr ui atau mungkin pula karena selama ini dia tidak pernah berbuat ulah dan selalu menyetor uang tiga ribu perak kepada penjaga panti.

\begin{tabular}{lll}
\hline Lima belas menit berlalu, Ray mengusap & Kata dia pada penggalan teks \\
tengkuknya. Gugup. Mendesis dalam hati, & disamping menunjukan Ray yang \\
sebenarnya apa yang sedang dilkukannya? & sedang bingung apa yang dilakukannya \\
Kenapa pula dia mencari-cari gadis itu & saat ini. Ray berpikir untuk apa \\
Kenapa pula dia berdiri disini? Bisa jadi & mencari-cari gadis itu, untuk apa Ray \\
malam itu dia salah lihat. Astaga, kalau & berdiri disini menunggu gadis itu. \\
pun benar terus kenapa? Gadis itu bukan & Lagipula gadis itu bukan siapa- \\
siapa-siapanya, bukan? Ray menelan & siapanya Ray. \\
ludah. (RTDW, 2009:242) &
\end{tabular}

Pada penggalan teks pertama kata dia menujukkan Diar yang tahu segala hal tentang penjaga panti yang Diar dapat dari cerita Reyhan yang menjadi teman sekamarnya selama dipanti, dan cerita orangorang yang menceritakan tentang tabiat buruk penjaga panti.Pada penggalan teks kedua kata dia menujukkan Diar yang tidak 
pernah dilecuti bilah rotan oleh penjaga panti mungkin karena tubuhnya yang ringkih atau mungkin pula karena selama ini dia tidak pernah berbuat ulah dan selalu menyetor uang tiga ribu perak kepada penjaga panti.Jika kita perhatikan dengan cermat kata dia pada kedua penggalan teks diatas berfungsi mengacu pada Diar, karena yang berbicara adalah pengarang novel memberitahukan kepada pembaca tentang kondisi Diar. Berbeda halnya dengan penggalan teks ketiga kata dia pada penggalan teks diatas menunjukkan Ray yang sedang bingung apa yang dilakukannya saat ini. Ray berpikir untuk apa mencari-cari gadis itu, untuk apa Ray berdiri disini menunggu gadis itu. Lagipula gadis itu bukan siapa-siapanya Ray.Jika kita cermati kata dia menunjukkan Ray yang sedang berbicara pada dirinya sendiri atau kepada pembaca.

Jadi dari ketiga penggalan teks diatas memiliki perbedaan dimana penggalan teks pertama dan kedua kata dia mengaju pada Diar yang digambarkan oleh pengarang sendiri kepada pembaca, bagaimana keadaan yang dialami oleh diar saat itu, sedangkan penggalan teks ketiga kata dia menunjukkan Ray yang berbicara pada dirinya sendiri untuk menjelasan kepada pembaca apa yang saat itu Ray rasakan.

Teks bacaan

Makna

Plee mengambil teropong bintang yang disiapkan dibagasi mobil. Hati-hati menyimak gedung sasaran mereka dari kejahuan. Plee menyapu bagian-bagian penting, mendesis pelan dengan nada riang, "Semua sesuai rencana!" (RTDW, 2009:179)

Pukul 01.11, pintu lift terbuka. Lift hanya bisa mengantarkan mereka hingga lantai 30. Terhenti. Lantai berikutnya membutuhkan akses khusus, karena lantai 30 hingga 40 disewa oleh salah satu bank internasional. Bank yang menyimpan berlian seribu karat di safety deposit box mereka. (RTDW, 2009:181)

Bukankah dia amat mencintai gadis itu? Bukankah kebersamaan mereka selama ini menyenangkan? Memberikan kebahagiaan yang tidak pernah dirasakannya. Seaneh apapun pola hubungan mereka, Ray merasakan indahnya perasaan mencintai seorang gadis. (RTDW, 2009:269)
Makna kata mereka yang pada penggalan teks disamping menunjukkan Plee dan Rayhan yang sedang melakukan pengintaian terhadap sasarn yang akan mereka incar.

Kata mereka pada penggalan teks diatas menujukkan Plee dan Ray yang sedang naik lift menuju lantai 40. Tetapi lift itu hanya mampu mengantarkan Plee dan Ray kelantai 30 karena pada lantai 30 dan 40 di sewa oleh salah satu bank internasional.

Makna kata mereka pada pengalan teks disamping menujukkan Ray dan gadisnya yang saling mencintai satu sama lain walau seaneh apapun pola hubungan mereka. 
Jika kita perhatikan penggalan teks pertama, kedua, dan ketiga kata mereka berfungsi mengacu pada Plee,Ray, dan Diar yang diceritakan oleh pengarang. Dimana kata itu dirujukan pembicara kepada orang yang berada diluar tindak komunikasi. Dengan kata lain kata mereka pada penggalan teks diatas hanya menegaskan kata ganti orang yang menjadi objek penjelasan dari seorang pengarang. Berbeda halnya dengan kutipan teks berikut: Lima belas menit berlalu, Ray mengusap tengkuknya. Gugup. Mendesis dalam hati, sebenanya apa yang sedang dilkukannya? Kenapa pula dia mencari-cari gadis itu?Kenapa pula dia berdiri disini?Bisa jadi malam itu dia salah lihat.Astaga, kalau pun benar terus kenapa?Gadis itu bukan siapa-siapanya, bukan?Ray menelan ludah.Benar.Apa pula yang dikerjakannya sekarang. Pelan Ray membalikkan badan (RTDW, 2009:242). Kata dia pada pada referensi personal merupakan salah satu kata ganti orang ketiga yang merujuk pada orang yang dibicarakan dengan kata lain bentuk kata ganti persona ketiga terkhusus pada kata dia merujuk pada orang yang tidak berada baik pada pihak pembicara maupun lawan bicara. Akan tetapi pada konteks kutipan teks diatas kita bisa perhatikan bahwa kata dia merujuk pada Ray yang bercerita pada dirinya sendiri, mengapa ia berada pada kondisi yang membingungkan hatinya. Jadi dia disini menujukkan Ray yang menjadi satu-satunya pembicara pada konteksnya yang masuk kedalam lingkup orang yang berada di tindak tutur itu.Berbeda halnya pada kata mereka dania pada penggalan teks diatas merupakan rujukan pembicara kepada orang yang berada diluar tindak komunikasi karena pengaranglah yang menjadi pembicara tunggal pada teks itu yang menceritakan kisah hidup dari orang yang dibicarakan dalam hal ini adalah Rinai dan gadis gigi kelinci.
Berrdasarkan pembahasan dari hasil penelitian diatas referensi persona yang digunakan pada novel rembulan tenggelam diwajahmu terkadang tidak berada pada kedudukan referensinya, melainkan kita harus mencermati referensi persona yang digunakan oleh penutur ataupun penulis terkadang berbeda pemaknaannya yang dimaknai oleh sipendengar ataupun sipembaca. Jika kita hubungkan pembahasan dari hasil penelitian dengan pendapat para ahli, ketika membicarakan pandangan semantik Lyon mengatakan bahwa hubungan antara kata dengan bendanya hubungan referensi. Pandangan kaum tradisional ini terus berpengaruh dalam bidang linguistik (seperti semantik leksikal) yang menerangkan hubungan yang ada itu adalah hubungan antara bahasa dengan dunia (benda) tanpa memperhatikan si pemakai bahasa tersebut. Tetapi Lyon pada pernyataan yang terbaru, ketika membicarakan referensi tanpa memperhatikan si pembicara tidaklah benar. Si pembicara paling tahu tentang referensi kaimatnya. Dari keterangan tersebut, dapat kita ketahui bahwa pada analisis wacana referensi itu dianggap sebagai tindak tanduk dari si pembicara atau penulis. Dengan kata lain, referensi dari sebuah kaimat sebenarnya ditentukan oleh si pembicara atau penulis. Kita sebagai pembaca atau pendengar hanya dapat menerka apa yang dimaksud (direferensikan) oleh si pembaca atau penulis.

\section{Simpulan}

Berdasarkan deskripsi data yang diuraikan di atas, dapat dikelompokkan beberapa bentuk referensi persona yang terdapat pada novel Rembulan Tenggelam 
Diwajahmu, yaitu : dia, ia, kita, saya, aku, mereka, kami, kau, dan engkau.

Dia artinya kata ganti yang menunjukkan orang ketiga dari apa yang dibicarakan oleh penutur wacana. Dalam hal ini penutur wacana secara langsung adalah pengarang.Pengarang novel ini sengaja menceritakan tokoh-tokoh dalam novel sebagai obyek pembicaraan antara pengarang dan pembaca.

Ia artiya kata ganti yang menunjukkan orang ketiga dari apa yang dibicarakan oleh penutur wacana dengan kata lain orang yang tidak terdapat pada area komunikasi, sama halnya dengan kata dia.

Saya dan aku merupakan bentuk tunggal kata ganti orang pertama dalam hal ini orang yang sedang berbicara sedangkan kata kami merupakan bentuk jamak dari kata ganti orang pertama yang lebih bersifat ekskulif artinya bentuk persona tersebut merujuk kepada orang yang ada dipihaknya.

Kita.Hal inilah yang menjadikan novel ini menjadi istimewa.Pengarang bukan saja bertutur cerita, juga mengajak pembaca seolah-olah pembaca menyaksikan peristiwa dalam novel yang direka oleh pengarang.Tujuannya agar pembaca menjadi yakin bahwa cerita ini benar terjadi tanpa pengaruh atau campur tangan pengarang.Pengarang meletakan dirinya sebagai orang luar yang menyaksikan peristiwa yang dilakukan tokoh-tokoh dalam novel.

Mereka.Jika pada bentuk kita maksudnya pengarang meyakinkan pembaca bahwa pengarang yang menceritakan tokohtokoh novel kepada pembaca.Pada bentuk mereka maksudnya pengarang mengajak pembaca terlibat menyaksikan peristiwa yang dilakukan tokoh-tokoh dalam novel.

\section{DAFTAR PUSTAKA}

Johari,Joy.2013. Kedudukan dan Fungsi Referensi Personal dalam Novel Safina Berkalung Jilbab.Skripsi Tidak Diterbitkan.Malang:UMM

Liye,Tere.2009.Rembulan Tenggelam di Wajahmu. Jakarta :Republika.

Munif. 2008. Bahasa: Pengertian, Karakteristik, dan Fungsinya. (Slide Presentasi).

Zuchdi, Darmiyati.1994. Metodologi

Penelitian Kualitatif. Yogyakarta: IKIP 